\title{
An intercultural, interpersonal relationship development framework
}

\author{
Jonna Koponen \\ University of Eastern Finland, Joensuu Campus, Joensuu, Finland \\ Saara Julkunen and Mika Gabrielsson \\ University of Eastern Finland - Kuopio Campus, Kuopio, Finland, and \\ Ellen Bolman Pullins \\ Ellen Bolman Pullins, John B. and Lillian E. Neff College of Business and Innovation, \\ University of Toledo, Toledo, Ohio, USA
}

\begin{abstract}
Purpose - The purpose of this paper is to explore how business-to-business (B2B), intercultural, interpersonal salesperson-customer relationships develop using the lens of identity management theory (IMT; Imahori and Cupach, 2005).

Design/methodology/approach - The research uses qualitative semi-structured interviews on 18 targeted relationships with customers from another culture conducted with business-to-business salespeople.

Findings - The findings indicate that our respondents' relationships moved from trial toward enmeshment and on occasion toward the renegotiation phase, as described in IMT. In the case of low cultural diversity between salesperson and customer, the relationships reached the trial and enmeshment phase. In the case of high cultural diversity between salesperson and customer, the relationships on occasion evolved toward the renegotiation phase. Salespeople's cultural intelligence (CQ) facilitates the development of interpersonal, intercultural salesperson-customer relationships.

Originality/value - The authors transfer IMT from the personal relationship development arena to B2B intercultural, interpersonal relationships, address a gap in the literature in the understanding of salespersoncustomer interpersonal relationships in different contexts and develop a theoretical model to understand intercultural, interpersonal salesperson-customer relationship development across different levels of cultural diversity.
\end{abstract}

Keywords Relationship development, B2B salespeople, Customer relationships, Identity management theory, Cultural intelligence, Cultural diversity

Paper type Research paper

\section{Introduction}

International salespeople and customers are embedded in different national cultures that almost inevitably affect their norms and communication behaviours (Voldnes et al., 2012; Nes et al., 2007). Today, sales relationships are changing rapidly (e.g. Arli et al., 2018; Dixon and Tanner, 2012), and marketing research shows customer-seller relationship depth is more critical to success when selling is more complex (e.g. Elo et al., 2015; Homburg et al., 2008; Palmatier, 2008). Business-to-business (B2B) solution selling entails solving customers' problems through developing customer relationships (Möller, 2011; Spekman and Carraway, 2006; Tuli et al., 2007). Firm-level research on solution selling (e.g. Tuli et al., 2007) has moved

(C) Jonna Koponen, Saara Julkunen, Mika Gabrielsson and Ellen Bolman Pullins. Published by Emerald Publishing Limited. This article is published under the Creative Commons Attribution (CC BY 4.0) licence. Anyone may reproduce, distribute, translate and create derivative works of this article (for both commercial and non-commercial purposes), subject to full attribution to the original publication and authors. The full terms of this licence may be seen at http://creativecommons.org/licences/by/4.0/ legalcode

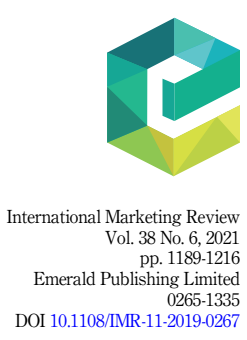


IMR

38,6

1190

toward a desire to understand interpersonal ties and the interaction between individual customers and sellers during the solution-selling process, particularly when parties come from different national cultures. When partners have different cultural backgrounds, this situation can lead to misunderstandings during interpersonal communication (Zhang et al., 2003) or to unresolved conflict with customers (Kauser and Shaw, 2004). Therefore, it is important to investigate how salespeople navigate their way through different cultural settings and how salesperson-customer relationships evolve at the interpersonal level in a cross-cultural context.

Although extant international marketing research on cross-cultural relationships reveals that the development of beneficial, rewarding firm-level relationships varies across cultures (Asseraf et al., 2019; Griffith et al., 2006; Hewett and Krasnikov, 2016; Hoppner et al., 2015), few previous studies have paid attention to the intercultural, interpersonal customer-salesperson relationship development process. Therefore, this study aims to examine how intercultural, interpersonal salesperson-customer relationships evolve in culturally diverse settings in the context of B2B solution selling by leveraging IMT (Imahori and Cupach, 2005). Compared with other theories (Altman and Taylor, 1973) or models (Dwyer et al., 1987) detailing customer relationship development across different phases, IMT is unique in emphasising the effect of culture on the development of this relationship.

A concept also associated with IMT and relationship development is social disclosure, which is defined as the level of personal information communicated when completing a sales task (Jacobs et al., 2001a). Furthermore, because previous studies have acknowledged that a salesperson's cultural intelligence (CQ) is important in the selling context (see, Chua et al., 2012; Imai and Gelfand, 2010; Moon, 2013), this study investigates how CQ may facilitate the development of intercultural, interpersonal salesperson-customer relationships. The paper will introduce the following research questions:

$R Q 1$. How do intercultural, interpersonal salesperson-customer relationships evolve in culturally diverse settings?

$R Q 2$. How does a salesperson's self-described cultural intelligence (CQ) contribute to the development of their intercultural, interpersonal salesperson-customer relationships?

In this study, a phenomenological approach has been adopted (Thompson et al., 1989; Riessman, 2004) to understand the richness of relationship development from the salesperson's perspective. The study makes the following contributions. First, it introduces IMT to the study of international marketing to enhance the theoretical understanding of intercultural, interpersonal relationship development. Secondly, this study is unique in focusing on the development of interpersonal B2B customer-salesperson relationships in culturally diverse settings. Despite interpersonal relationships being critical, research tends to focus on firm-level relationships (Homburg and Stock, 2004; Morgan and Hunt, 1994; Wuyts and Geyskens, 2005). Considering the many relationship development studies available (e.g. Palmatier et al., 2013), few focus on relationship development at the interpersonal level in cross-cultural settings. Third, focus is placed on salespeople's descriptions of their CQ, and to show how such a CQ facilitates the development of intercultural, interpersonal salesperson-customer relationships. Finally, a framework to advance the understanding of intercultural, interpersonal relationship development is introduced.

\section{Literature review}

In the following literature review, previous research in the field of international marketing is synthesised through three main themes. For the literature review, this study used a selected part of the earlier research in each area to illustrate comprehensive research related to this 
phenomenon. First, the study focuses on previous studies on customer relationship development. Secondly, it looks at previous research concerning cultural diversity between partners. Third, focus is placed on communication in intercultural customer relationships. Then, this study introduces identity management theory (IMT), which is applied in this research. The underlying theoretical tenets, key concepts, underlying assumptions, and limitations of IMT are summarised in Table 1 which also shows how IMT is integrated within the previous research in the field of international marketing. Following this, the main concepts related to this study are connected with IMT. These are social disclosure, lowcontext, and high-context cultures, and cultural intelligence. At the end of the literature review, a visualisation of this study's framework is developed to show the reader how the theoretical concepts are connected with the methodology and data analysis of this study.

\section{Previous research on customer relationship development}

In the field of international marketing, researchers have recognised that the development of effective firm-level relationships is largely dependent on both interorganizational and interpersonal relationships (Barnes et al., 2015; Alteren and Tudoran, 2018; Leonidou et al., 2017; Miocevic, 2016). Interorganizational and interpersonal relationships have been investigated in the context of international marketing networks with a focus on the factors driving a successful export network at the interorganizational and interpersonal levels (e.g. Ghauri et al., 2003; Gummesson, 2008; Halinen et al., 2013; Khakhar and Rammal, 2013; Rammal, 2005). In addition, interorganizational exchange has been examined through a combination of formal and informal proceedings, underlying a set of interpersonal interactions and social-psychological dynamics between boundary spanners in an attempt to explain why and how these interfirm processes develop (Barnes et al., 2015).

Following Dwyer et al.'s (1987) description of the buyer-seller relationship as an ongoing process, relationship marketing research has gradually incorporated studies of relationship trust (Fang et al., 2008; Morgan and Hunt, 1994), commitment (Bansal et al., 2004; Homburg et al., 2014; Palmatier et al., 2013), and the human interaction required to build long-term customer relationships (Elo et al., 2015). Focusing particularly on trust, Fang et al. (2008) state that managing and building trust at both the interorganizational and at the interpersonal level is central to successful interorganizational marketing collaboration. In addition, Zhang et al. (2003) investigated trust and showed the mediating role of trust when relational governance was investigated in cross-border relationships. Alteren and Tudoran (2018) show that for trust-building, communication is important, irrespective of cultural differences. In the most current marketing research, Zhou et al. (2020) state that a business relationship is mediated by interfirm trust and relationship-specific investment underlying both the roles of interorganizational relationships and interpersonal relationship-building. Business partners typically foster a personal relationship orientation to show their commitment and maintain close relationships (Esper et al., 2015). Indeed, many firm-level characteristics, such as interfirm trust, are based on personal interactions between partners (Barnes et al., 2015; Fang et al., 2008; Wuyts, 2007; Zhou et al., 2020).

Furthermore, current international marketing research emphasises that business relationships are not static but dynamic and thus can move through several transitions during the relationship (e.g. Leonidou et al., 2017). However, considering the many relationship development studies available (e.g. Palmatier et al., 2013), little empirical research focuses on relationship development in interpersonal, intercultural relationships. Therefore, this study responds to the call of Zhou et al. (2020) for more research on the process of interfirm relationships that develop between individuals. The study focuses on obtaining a detailed understanding of how salesperson-customer
Intercultural relationships development 
IMR

38,6

1192

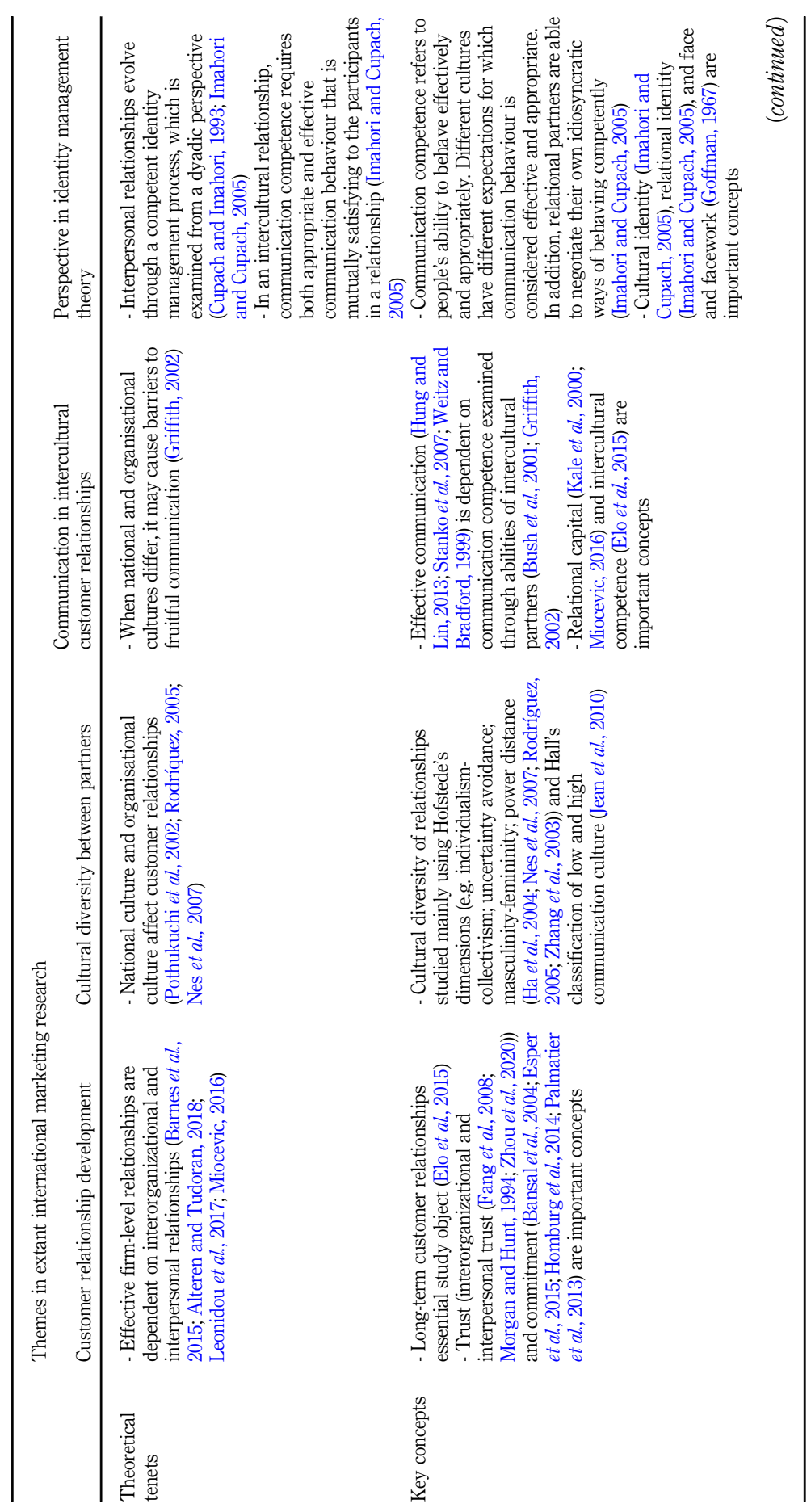

Table 1.

Identity management theory in relation to extant research in the field of international marketing 


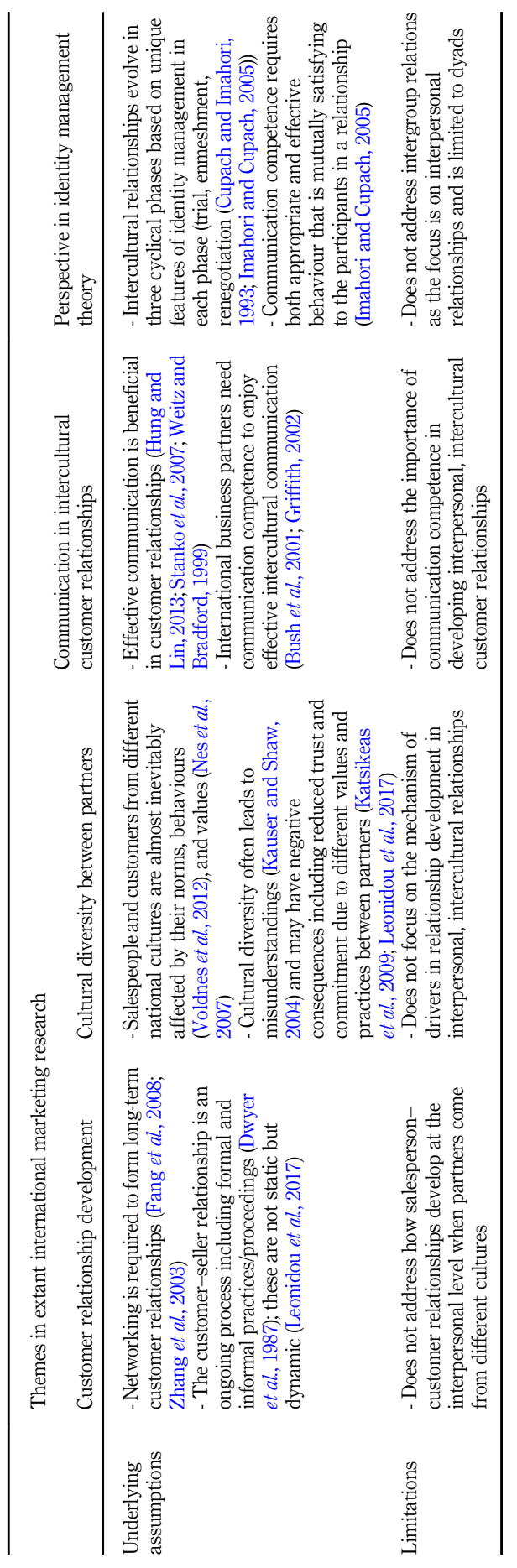

Intercultural relationships development

1193

Table 1. 
IMR

38,6

relationships develop at the interpersonal level when a salesperson and customer are from different cultures.

\section{Cultural diversity between partners}

International salespeople are embedded in different national cultures that almost inevitably affect their norms, behaviours (Voldnes et al., 2012), and values (Nes et al., 2007), a situation that often leads to misunderstandings or even to unresolved conflict with their customers (Kauser and Shaw, 2004). In cross-cultural relationships, the uncertainty, complexity, and volatility of the international business environment can cause expectations to be breached (Katsikeas et al., 2009; Leonidou et al., 2017). Rodríguez (2005) suggests that if adequately balanced, individualism-collectivism is a source of intercultural fit while building shared leadership between international partners. However, the few studies that explore the influence of distinct cultures on buyer-seller relationships are of relatively limited scope (Cannon et al., 2010; Voldnes et al., 2012) but they do affirm that national cultures can affect repurchase intentions and also be reflected in corporate culture (Hewett et al., 2006).

National and organisational cultures have an impact on the degree of organisational involvement and outcomes in international ventures (e.g. Pothukuchi et al., 2002; Rodríquez, 2005). Nes et al. (2007) showed that national cultural differences in exporter-distributor relationships have a significant impact on trust and commitment. Furthermore, the same study showed that communication can influence trust and commitment in a different way than in domestic relationships, where the degree of commitment to the distributor from another culture was directly related to financial performance (Nes et al., 2007).

This study agrees with those marketing scholars who confirm that culture matters in business relationships (e.g. Nes et al., 2007). Often cultural diversity in interorganizational relationships has been investigated by applying Hall's classification of communication culture (Jean et al., 2010) or Hofstede's dimensions (Ha et al., 2004; Nes et al., 2007; Rodríguez, 2005; Zhang et al., 2003). Jean et al. (2010) investigated relationship learning in cross-border customer-supplier relationships and found that relationship learning was stronger and more significant when both supplier and buyer were from high-context cultures. Interestingly, research applying Hofstede's dimensions has often produced mixed results (see, e.g. Jean et al., 2010). Zhang et al. (2003) and Ha et al. (2004) state that Hofstede's indexes do not significantly explain behavioural relationship variables in exporter-importer relationships. This might be because Hofstede's dimensions explain national culture level differences, and interorganizational relationships are individual or group level phenomena. Although prior marketing research has often identified cultural diversity as a problem that must be resolved in international business relationships, the mechanism of the drivers of relationship development remains unclear. Despite the extensive coverage of relationship marketing literature, there is, therefore, a lack of comprehensive understanding of how interpersonal, intercultural salesperson-customer relationships evolve.

\section{Communication in intercultural customer relationships}

Studies of interpersonal customer relationships in business settings highlight the benefits of effective interpersonal communication (Hung and Lin, 2013; Stanko et al., 2007; Weitz and Bradford, 1999). Effective communication is particularly important in intercultural business negotiations. Previous studies have, for example, focused on how negotiations are conducted by Arab managers (Khakhar and Rammal, 2013), or more specifically how negotiations are conducted in Pakistan (Rammal, 2005).

When national and organisational cultures are inconsistent, it is believed that this can result in culturally inconsistent communication because partners (e.g. from Japan and the USA) have different cultural orientations and different communication styles (Griffith, 2002). 
This is seen as a barrier to fruitful communication. However, when partners come from similar national and organisational cultures, their mode of communication is culturally consistent, which reduces communication barriers (Griffith, 2002). To overcome cultural barriers in communication, researchers have suggested that international business partners require communication competence (Bush et al., 2001; Griffith, 2002), relational capital (Kale et al., 2000; Miocevic, 2016), or intercultural competencies (Elo et al., 2015). According to Griffith (2002, p. 258) "communication competence is a set of abilities and knowledge related to communication that enables an individual to engage in appropriate/meaningful communications with international partners". In addition to being adaptive, Bush et al. (2001) showed that the intercultural disposition of a marketer is of key importance in developing intercultural communication competence. Kale et al. (2000) write that relational capital develops trust between partners, and encourages close personal interaction, respect, and even friendship. Relational capital in the context of business relationships is "the mutual trust, respect, reciprocity, close personal interaction, and friendship that emerge between constituencies in business relationships" (Miocevic, 2016, p. 197).

The literature review conducted as part of this study indicates that customer relationship development, cultural diversity between customer and seller, and communication competence in intercultural customer relationships have been extensively studied in previous international marketing literature. However, a theory is required to help one understand how salesperson-customer relationships develop in culturally diverse settings. To address this shortcoming, IMT is introduced to show how it can be leveraged to explore the development of intercultural, interpersonal salesperson-customer relationships in the context of B2B solution selling.

\section{Identity management theory}

Identity management theory (Cupach and Imahori, 1993; Imahori and Cupach, 2005) explicates how cultural identities are negotiated through the development of interpersonal relationships. The theory explains competent identity management across three cyclical developmental phases: trial, enmeshment, and renegotiation. The relationship development phases range from initial acquaintance to a relationship that features intimacy and commitment between partners (Imahori and Cupach, 2005). Identity management theory has its roots in interpersonal relations and focuses on dyads, person-to-person communication, and interpersonal relationship development through competent identity management (see Imahori and Cupach, 2005). The underlying theoretical tenets, key concepts, underlying assumptions, and limitations of IMT are summarised in Table 1, which also shows how IMT is integrated within the previous research in the field of international marketing.

Different cultures have different expectations of effective communication behaviours (e.g. those achieving goals) and appropriate communication behaviours (e.g. those emphasising politeness), which help explain relationship development between partners. In IMT, identity — as self-conception (Cupach and Imahori, 1993) — serves as a framework for understanding the self and the surrounding world. Imahori and Cupach (2005) hold that each person's identity comprises numerous overlapping aspects (e.g. nationality, occupation, and social groups), although IMT focuses specifically on cultural and relational forms of identity (Imahori and Cupach, 2005). Cultural identity is defined as "identification with and perceived acceptance into a group that has shared systems of symbols and meanings as well as norms/rules for conduct" (Imahori and Cupach, 2005, p. 197). It refers to people's understanding of their cultural identity, and cultural identity encompasses all types of identities associated with cultural and social groups. In IMT, cultural identity is most evident at the beginning of the interpersonal relationship. In contrast, relational identity is "born out of shared relational culture, that is, 'a privately transacted system of understandings' that
Intercultural relationships development

1195 
IMR 38,6

1196

helps people coordinate meanings and behaviours" (Imahori and Cupach, 2005, p. 197). Relational identity is more evident as the relationship evolves toward the enmeshment and renegotiation phases.

At the beginning of the relationship, known as the trial phase, partners are expected to be polite to initiate the connection, even though a tendency exists to stereotype a partner from a different cultural background (Littlejohn and Foss, 2010). The early, relatively superficial phase thus involves trial-and-error processes, as partners explore their cultural differences and try to find shared identities (Imahori and Cupach, 2005). However, the cultural differences do tend to be salient and may create barriers to the development of the relationship (Littlejohn and Foss, 2010).

Then, in the enmeshment phase, "intercultural partners begin to develop a mutually acceptable and convergent relational identity, in spite of the fact that their cultural identities are still divergent" (Cupach and Imahori, 1993, p. 125). Partners begin to sense their similarities, accept familiarity in their relationship, and adopt a future outlook (Littlejohn and Foss, 2010).

Finally, according to IMT, in the renegotiation phase, partners have strong relational identities that they can rely on (Littlejohn and Foss, 2010). Cultural differences become relatively easier to manage, partners accept that they have different personalities, come from distinct cultural environments (Imahori and Cupach, 2005), and that they can have different expectations and express disagreement in each other's presence. According to Cupach and Imahori (1993), these three phases are cyclical; partners may go through them as they form, maintain, and develop intercultural relationships, but the relationship deepens as it proceeds toward more advanced stages.

IMT is strongly influenced by the notion of facework, or "actions taken by a person to make whatever he is doing consistent with face" (Goffman, 1967, p. 12). The notion of face reflects the desired social image that a person creates through interactions with others (Cupach and Carson, 2002; Goffman, 1967). According to Lee (2008), when communicating with people with similar cultural backgrounds, it is easier to support others' face, owing to the shared cultural norms. However, intercultural communication creates a greater threat to the other person's face, because of a lack of knowledge of others' cultural rules and norms. Therefore, interpersonal relationship development requires a person to be able to perform facework, both to establish his or her face and to protect the relational partner's face (Imahori and Cupach, 2005).

IMT has largely been applied to investigate the development of personal intercultural friendships (Lee, 2008), the formation of intercultural friendship focusing, for example, on Japanese students at an Australian university (Kudo and Simkin, 2003), or work relationships to explain communication and business relationship development in creative projects (Stock, 2012). Nevertheless, as far as can be ascertained, IMT has not been applied in the international marketing field. Some studies explore the use of face-enhancing strategies to deal with rejected customer ideas (Fombelle et al., 2016), but it is believed that the current study represents the first application of IMT to the development of intercultural, interpersonal salesperson-customer relationships.

\section{Social disclosure in relation to IMT}

Social disclosure may be required when developing interpersonal relationships through facework. In a sales context, there are a few studies investigating disclosure among salespeople, which might be either task-specific or social (e.g. Jacobs et al., 2001a, b). Taskspecific disclosure involves information related to business purposes (Jacobs et al., 2001a), which must be disclosed for the transaction to occur. Social disclosure, in contrast, refers to personal information (e.g. personal interests) communicated during the execution of the sales task (Jacobs et al., 2001a). Such disclosure is in line with social penetration theory (Altman and 
Taylor, 1973), which explains how interpersonal relationships develop over time and deepen, involving more trust as people gradually and voluntarily reveal themselves (Baack et al., 2000).

Social disclosure in sales contexts can be described with reference to three properties: duration (seconds), number (breadth), and intimacy (depth) (Jacobs et al., 2001a). In this study, focus is placed on depth, operationalised as the highest level of intimacy evidenced in the data. This property offers the clearest explanation of how people move from the superficial to an intimate level in their relationships (Altman and Taylor, 1973; Baack et al., 2000; Jacobs et al., 2001a, b).

Social disclosure is associated with the relationship development depicted by IMT which also essentially includes facework, that is, how people manage the impressions others have of them. A central aspect of successful facework is how much personal information shared with others. As IMT explains, at the beginning of the relationship, politeness is essential (Imahori and Cupach, 2005), and therefore rather superficial disclosures could be expected to emerge between partners. As the relationship evolves toward the enmeshment phase, partners start to develop their relational identity (Imahori and Cupach, 2005), and therefore more intimate social disclosure could be expected to occur. Finally, as the relationship develops to the renegotiation phase, partners have a strong relational identity (Imahori and Cupach, 2005), and therefore the most intimate social disclosure could be expected to occur at this stage.

\section{Low-context and high-context cultures in relation to IMT}

In IMT, intercultural relationships are those that exist between two different cultures. Research has shown that cultural differences exist across countries (e.g. Hall, 1977; Hall and Hall, 1990). Hall (1977) specifically considers the impact of culture on communication known as cultural distance, that is, how people communicate with others through their range of communication abilities (Hall, 1977). Consistent with this focus on communication, Hall (1977) explains that to communicate effectively with someone from a different culture, a person must decode the message to make it consistent with his or her cultural norms (Rosenbloom and Larsen, 2003). Hall's (1977) simple, two-category framework groups different countries into low-context (LC) and high-context (HC) communication cultures. In LC cultures (e.g. the United States or Germany), the information is contained mainly in the message itself; what is said is what is meant. The message must be detailed and explicit (Hall and Hall, 1990; Rosenbloom and Larsen, 2003). In contrast, in HC cultures (e.g. China or Italy), the information conveyed in the message is less explicit and parties must rely on the context of the communication to understand the message. Personal relationships are more important in HC cultures because they help clarify the message (Rosenbloom and Larsen, 2003). Cultural contexts are likely to have different impacts on the development of relationships when the relationship is marked by less diversity (LC-LC or HC-HC) rather than more (LC-HC). Accordingly, this study investigates how the extent of cultural diversity interacts with relationship development. Given the importance of interpersonal communication to the salesperson-customer relationship, Hall's (1977) framework is well-suited to the purpose of examining those relationships.

\section{Cultural intelligence in relation to IMT}

Customer-salesperson relationship development in B2B solution selling may involve navigating different cultural contexts. Therefore, another important consideration is whether a salesperson has the ability to navigate these differences. In intercultural marketing settings, salespeople need cultural intelligence (CQ), defined as the ability to function, effectively manage, and behave appropriately in culturally diverse settings (Earley and Ang, 2003; Hansen et al., 2011). The CQ construct is multidimensional in that it has cognitive,
Intercultural relationships development 
IMR

38,6

1198

metacognitive, behavioural, and motivational components that may or may not correlate. Accordingly, a person might have a great deal of knowledge about a particular culture but lack the ability to act on that knowledge (Hansen et al., 2011).

$\mathrm{CQ}$ is viewed as a communication competence that is an essential element of IMT [1]. This study has chosen to employ CQ as it explains competent communication behaviour in culturally diverse settings, and because direct evidence from psychology and management literature indicates that $\mathrm{CQ}$ is relevant to international marketing. For example, CQ has been applied when conceptualising the understanding of success/survival factors of rich-to-poor diaspora entrepreneurship (Harima et al., 2016). In addition, CQ should be considered when selecting, providing support to, and training expatriates (see Wu and Ang, 2011). Drawing on social exchange theory, Paparoidamis et al. (2019) examined how frontline employees' CQ influences customer perceptions of service quality. Specifically, Paparoidamis et al. propose that the three components of $\mathrm{CQ}$ - the cognitive, emotional/motivational, and physical have differential moderating effects on perceived service quality.

$\mathrm{CQ}$ is also relevant in B2B selling situations. Sales research emphasises how a salesperson's adaptability is a crucial factor in customer relationship development (Spiro and Weitz, 1990). By extension, an international salesperson's CQ should affect relationship development in a culturally diverse situation. The presence of CQ can improve multicultural team performance (Moon, 2013) and trust-building (Chua et al., 2012). Imai and Gelfand (2010) demonstrate that $\mathrm{CQ}$ also increases the effectiveness of intercultural negotiation. Looking specifically at sales situations, Chen et al. (2012) show that the motivational dimension improved sales across culturally diverse populations in a real-estate setting. However, there is no knowledge of studies that explore the role of salespeople's CQ in facilitating intercultural, interpersonal relationship development in a $\mathrm{B} 2 \mathrm{~B}$ context.

Figure 1 illustrates the framework guiding the methodological choices and data analysis in this study, the context of which is B2B solution selling. The object of the study is intercultural, interpersonal salesperson-customer relationship development. According to IMT, intercultural relationships evolve in three phases including different types of identity and social disclosure. This study investigates salesperson-customer relationship development in culturally diverse settings: in combinations of low-low and low-high cultures. The factor that might influence the development of intercultural, interpersonal salesperson-customer relationships is the salesperson's self-reported CQ. Based on IMT and previous research in the field of international marketing, cultural diversity between partners may hinder salesperson-customer relationship development.

\section{Methodological approach}

To understand the development of intercultural, interpersonal salesperson-customer relationships from the perspective of the salesperson, a phenomenological approach (Thompson et al., 1989; Riessman, 2004) was utilised. As Cope (2005, p. 168) stated, the "aim of

Figure 1.

Framework for intercultural, interpersonal salesperson-customer relationship development leveraging IMT
Salesperson's CQ is needed for relationship development

\begin{tabular}{|l|l|l|l|l|}
\hline $\begin{array}{l}\text { Trial phase } \\
\text { - Cultural identity }\end{array}$ & $\begin{array}{l}\text { Enmeshment phase } \\
\text { - Superficial social } \\
\text { disclosure }\end{array}$ \\
\hline
\end{tabular}


phenomenological inquiry is to understand the subjective nature of 'lived experience' from the perspective of those who experience it, by exploring the meanings and explanations that individuals attribute to their experiences". The methodological choice in this study was to use semi-structured interviews to collect data and to analyse those data via qualitative content analysis (Miles and Huberman, 1994). The interviews conducted focused on the perceived experiences of the interviewees and aimed to allow salespeople to describe their lived meanings (Cope, 2005; Haytko, 2004).
Intercultural relationships development

1199

\section{Data sourcing}

To create a clear sampling logic, specific criteria was defined (Miles and Huberman, 1994): all relationships had to occur in an international, B2B solution-selling context and be identified as long-term by the salespeople (Haytko, 2004); interviewees were also asked to focus on profitable relationships. The customer relationships were to be on-going, and still profitable over time. The sample was designed to include companies involved in solution selling (Terho and Halinen, 2012), which comprises "individualised offers for complex customer problems that are interactively designed and whose components offer an integrative added value by combining products and/or services so that the value is more than the sum of the components" (Evanschitzky et al., 2011, p. 657). Sharma et al. (2008) define solution selling as an approach adopted by leading companies where the salesperson has the role of problemsolver, and moreover, has responsibility for developing the relationship with the customer. Solution selling requires that salespeople understand the problems of their customers and actively seek solutions for the customer firm (Liu and Leach, 2001). In this sense, solution selling always involves both interorganizational and interpersonal levels of the relationship.

For the interviews, nine salespeople were selected, who between them had 10-45 years of employment experience, worked for three companies (see Table 2), and all came from an LC culture (Finland). The nine salespeople each identified two important long-term customer relationships, one from an LC culture and one from an HC culture (Hall, 1977) [2]. These customer relationships were with people from a variety of countries (see Table 2). Therefore it was possible to analyse 18 salesperson-customer relationship cases. The respondents provided a subjective perspective on the development of interpersonal relationships with customers in the two different contexts (both low and high levels of cultural diversity). To ensure external validity, two customers (one from an LC culture and another from an HC culture) were interviewed to verify and triangulate the data. The customers' perspectives confirmed the descriptions of the relationships acquired from the salespeople. Among the nine salespeople interviewed, three were interviewed four times (accounting for 12

\begin{tabular}{|c|c|c|c|c|}
\hline Informant** & Age & Gender & $\begin{array}{l}\text { Relationship with low } \\
\text { cultural diversity }\end{array}$ & $\begin{array}{l}\text { Relationship with high } \\
\text { cultural diversity }\end{array}$ \\
\hline Salesperson A, Construction industry & 38 & Male & Swedish customer & Russian customer \\
\hline Salesperson B, construction industry & 41 & Male & Swedish customer & Russian customer \\
\hline Salesperson C, construction industry & 52 & Male & Estonian customer & Russian customer \\
\hline Salesperson D, paper industry & 55 & Female & German customer & Korean customer \\
\hline Salesperson E, paper industry & 52 & Male & Danish customer* & Spanish customer \\
\hline Salesperson F, paper industry & 58 & Male & German customer & Italian customer* \\
\hline Salesperson G, Software industry & 50 & Female & Swedish customer & Chinese customer \\
\hline Salesperson H, Software industry & 43 & Male & Swedish customer & Indian customer \\
\hline Salesperson I, Software industry & 47 & Male & Swedish customer & Israeli customer \\
\hline
\end{tabular}

Note(s): * This customer was interviewed to confirm the salesperson's perspectives **All salespeople were Finnish

Table 2. Interviewees 
IMR 38,6

1200

interviews) and six were interviewed twice (accounting for a further 12 interviews). The two customer interviews brought the total to 26 interviews relating to the 18 relationships on which analysis could be based. Each of the 26 interviews lasted between 60 and $140 \mathrm{~min}$, and the same structure and questions were used for all the salespeople and customers (see Table 2).

The interviews began with background questions, then gathered information by requesting a chronological account of the development of the customer relationship from initiation to the present. The resulting discussions focused on the cultural benefits and hindrances experienced in various phases of relationship development and how the parties tried to overcome the hindrances. In addition, descriptions were elicited of social disclosure during different relationship phases through questions such as; "How was the customer relationship formed, developed, and maintained?"; "How would you describe the nature of this particular relationship?"; "What effects did cultural differences between yourself and your customer have on business operations and customer relationship development?"; "What did you due to ensure you were acknowledging the customer's cultural identity (face)?"; "How would you describe communication with customers from different cultural environments?"; and "How would you describe your ability to behave appropriately in culturally diverse settings?"

Both a detailed and holistic understanding of the key phenomena was provided through the interviews (Graebner, 2009). The interviewer then later interviewed the respondents about the opposite context relationship; that is, if the salesperson had first identified an LC example, the researcher subsequently asked the salesperson to identify an HC relationship and vice versa. Finally, using interview data and the interviewers' observations, salesperson CQ was analysed. The researchers who had conducted the qualitative interviews analysed the salesperson's CQ based on questions that tapped into how capable each person felt in terms of the various dimensions of $\mathrm{CQ}$.

\section{Analysis}

Each interview was audiotaped and transcribed. Initially, three researchers systematically reviewed the transcribed interview data, following "a series of hermeneutic circles through a combination of data gathering, analysis, and reflection" (Viio and Grönroos, 2016, p. 39). Textual interpretations were clarified through new reflections, focusing on similarities and differences, which helped broaden and strengthen the thematic structure of the findings (Haytko, 2004). Each relationship was analysed separately, using qualitative content analysis (Miles and Huberman, 1994), enabling the authors to formulate themes (Makkonen et al., 2012) and meaning-based categories (Haytko, 2004). It is understood that creating meanings is always a process that is located in a person's experience.

The data was first divided into two datasets: the first dataset incorporated salespersoncustomer relationships with low cultural diversity between partners and the second dataset incorporated salesperson-customer relationships with high cultural diversity between partners.

The second step of the analysis involved analysing how intercultural, interpersonal salesperson-customer relationships evolve and isolating three phases within those relationships (trial, enmeshment, and renegotiation). Moreover, social disclosure was analysed in different phases of the relationship. Social disclosure refers to personal information communicated during the development of the salesperson-customer relationship. In the data from this study, the depth of the social disclosure increased in conjunction with the following themes: (1) superficial social disclosure (e.g. small talk or talk of educational background); (2) more intimate social disclosure (e.g. hobbies, interests, family relations, children, common interests, personal values, personal life history, plans); (3) most intimate social disclosure (e.g. disabilities, shameful incidents, and failures). 
Following this, the third step analysed how intercultural, interpersonal salespersoncustomer relationships evolve in culturally diverse settings. Therefore an analysis was made on how salesperson-customer relationships evolve in three phases when cultural diversity between the partners is low (LC-LC cultural diversity) or high (LC-HC cultural diversity). Then, as the fourth step in this process, salespeople's cultural intelligence was analysed (CQ) based on their descriptions of it during the customer relationship development process (see Figure 2).

As a check on reliability and validity, follow-up questions were also posed by telephone if any clarification was required (Miles and Huberman, 1994). Finally, summaries of the interviews reflecting the understanding of all the data were sent to the interviewed salespeople for review. This member checking stage (Miles and Huberman, 1994) can be considered an additional interview (Haytko, 2004), which provided pure feedback, focused on similarities and differences between the informants' understanding and researchers' analysis of the phenomena. Interviews were conducted and analysed by native Finnish speakers from the multinational research team, legitimising the interpretations made regarding Finnish solution sellers. To acquire as comprehensive an understanding as possible, salespeople were selected from diverse companies and industries. As with any interviews, bias may exist in what and how the participants choose to share data, but it is believed that the protocols and triangulation used in this research help mitigate any systemic bias. Nonetheless, there is always a possibility of bias as respondents may have presented their behaviour and the events with a positive slant that might not have been fully endorsed by other protagonists.

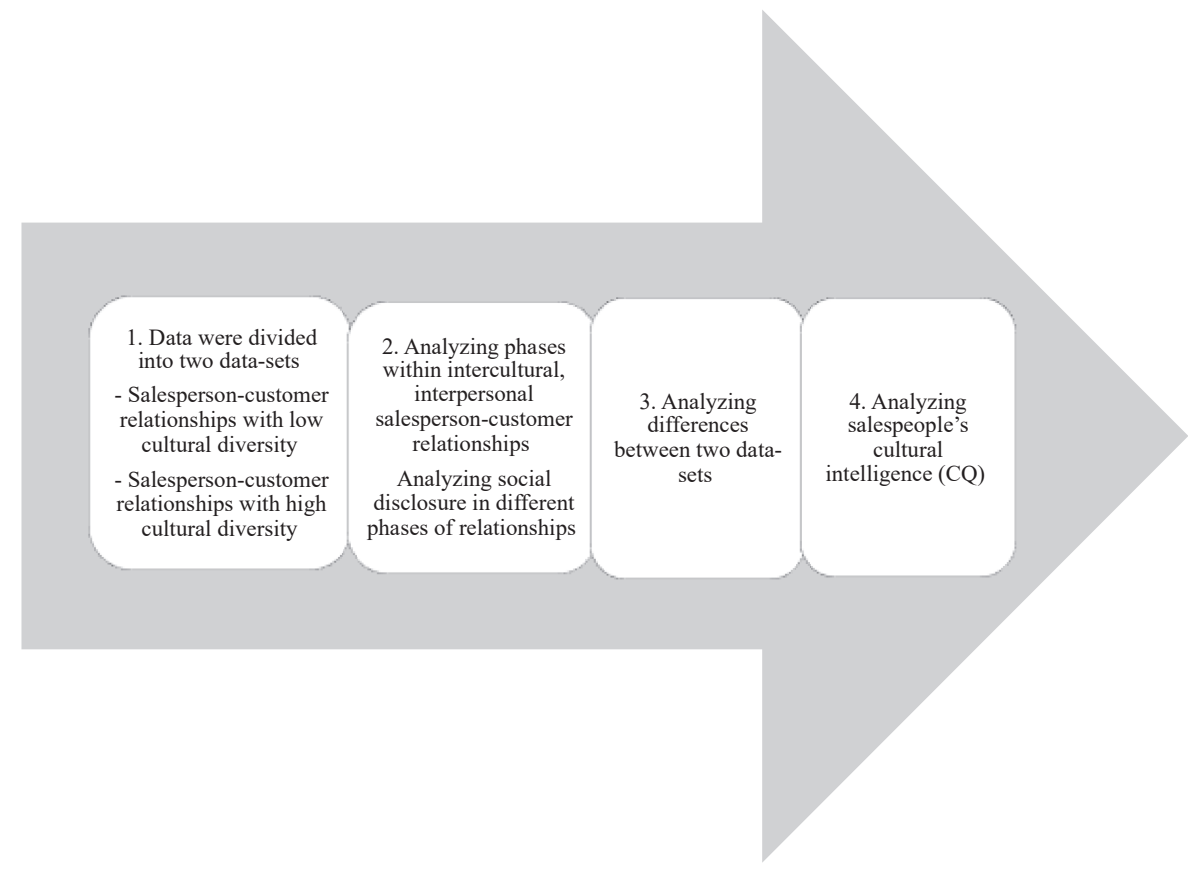

Figure 2.

The analysis process of the study

Intercultural relationships development 
IMR

38,6

1202

\section{Empirical findings}

The analysis revealed the salesperson-customer relationships experienced and interpreted by the interviewed salespeople moved from the trial phase toward enmeshment and then renegotiation (Cupach and Imahori, 1993; Imahori and Cupach, 2005). The findings suggest that the relationship phases described by IMT theory do apply to intercultural, interpersonal salesperson-customer relationships. The phases and main themes found related to social disclosure are summarised in Table 3.

\section{Intercultural, interpersonal customer-salesperson relationship phases}

In the initial trial phase, both salesperson and customer start to explore their cultural differences but will retain their own separate cultural identities. It is not a prerequisite for the relationship to advance that partners develop a relational identity during the trial phase. The following example from the data shows how salesperson $\mathrm{H}$ reflected on the trial phase of the relationships.

I think the seller does not have to know the person [their cultural identity] at the beginning and the buyer does not have to know the seller. (Salesperson H)

Furthermore, as the salesperson and the customer do not know each other particularly well on a personal level, their conversations and social disclosure are at a fairly superficial level. The findings show that in the intercultural, interpersonal salesperson-customer relationships in place during the trial phase, the content of superficial social disclosure included small talk, sharing information on each other's educational background, and perhaps talking about hobbies and interests. Examples of this type of discourse are provided in the following excerpts.

Small talk, educational background: It depends on the time of year; I mean you can talk about the summer vacation and your plans for summer. (Salesperson $\mathrm{H}$ )

Hobbies, interests: Hobbies come up in conversation such as "Do you want to see an ice hockey match?" (Salesperson I)

Once the interpersonal, intercultural salesperson-customer relationship reaches the enmeshment phase, the partners start to reveal who they are as people. This naturally

\begin{tabular}{|c|c|c|}
\hline $\begin{array}{l}\text { Relationship phase } \\
\text { based on IMT (Imahori } \\
\text { and Cupach, 2005) }\end{array}$ & Phases emerging in the data & $\begin{array}{l}\text { Social disclosure themes emerging in the } \\
\text { data }\end{array}$ \\
\hline Trial & $\begin{array}{l}\text { "I think the seller does not have to know the person } \\
\text { [their cultural identity] at the beginning and the } \\
\text { buyer does not have to know the seller" (Salesperson } \\
\text { H) }\end{array}$ & $\begin{array}{l}\text { Superficial social disclosure } \\
\text { - Small talk, educational background } \\
\text { - Hobbies, interests }\end{array}$ \\
\hline Enmeshment & $\begin{array}{l}\text { "For us, a small failure [understanding cultural } \\
\text { differences] and investigating it deepened the } \\
\text { relationship. There was no need for [face-to-face] } \\
\text { meetings every single time. The content of the } \\
\text { discussions included feedback and talking about } \\
\text { even the most difficult things in a very natural way" } \\
\text { (Salesperson H) }\end{array}$ & $\begin{array}{l}\text { More intimate social disclosure } \\
\text { - Family relations, kids, common interests } \\
\text { - Personal values, personal life history, } \\
\text { plans }\end{array}$ \\
\hline Renegotiation & $\begin{array}{l}\text { "Things go well when you know each other ... that } \\
\text { relationship has helped me understand what it means } \\
\text { to be Italian and to work in Italy and to appreciate } \\
\text { things there. The customer started to trust our way of } \\
\text { working" (Salesperson F) }\end{array}$ & $\begin{array}{l}\text { Most intimate social disclosure } \\
\text { - Intimate subjects (e.g. disabilities, } \\
\text { shame, failures) }\end{array}$ \\
\hline
\end{tabular}

Table 3.

Results on intercultural, interpersonal customer-salesperson relationship phases 
takes time and occurs after the parties have worked together for a longer period. One salesperson described the enmeshment phase in the following way.

For us, a small failure [in understanding cultural differences] and investigating it deepened the relationship. There was no need for [face-to-face] meetings every single time. The content of the discussions included feedback and talking about even the most difficult things in a very natural way. (Salesperson H)

The preceding excerpt also shows how partners were able to talk about the most difficult issues. The findings show that social disclosure moved toward more intimate sharing and came to include talking about family relations, children, common interests, personal values, personal life history, and plans. Examples of this type of social disclosure are shown below.

Family relations, kids, common interests: I ask how it's going with the family. (Salesperson B)

Personal values, personal life history, plans: We get to know each other more deeply, talk about what he has been doing previously in his career, what schools he went to, what kind of mentors he had, and what kind of ambitions he has for the future. (Salesperson $\mathrm{H}$ )

According to IMT, during the renegotiation phase cultural differences should be easier to manage, and partners come to accept that they are different personalities from distinct cultural environments (Imahori and Cupach, 2005). The partners are aware of cultural differences between them in the relationship. The following excerpt shows how Salesperson $\mathrm{F}$ and his customer describe the relationship during the renegotiation phase.

Things go well when you know each other so well ... this relationship has helped me understand what it means to be an Italian and to work in Italy and to appreciate things there. The customer started to trust our way of working, even though it is the Finnish way. (Salesperson F).

It was really easy to share some common experiences and to speak about family problems. To identify with my life. (Italian customer of Salesperson F).

With regard to social disclosure, the findings reveal that the most intimate social disclosure occurred between partners when the salespeople felt that they were in the renegotiation phase of the relationship. The content of social disclosure included sharing extremely personal issues, such as talking about physical disabilities, talking about emotions such as shame, and disclosing personal failures in working life (bankruptcy) or personal life issues (divorce). During the renegotiation phase, partners were also involved in each other's private lives. For example, Salesperson I described being invited to a funeral in Israel and Salesperson $\mathrm{H}$ was invited to a wedding in India by the customer. In addition, Salesperson F described how he was involved in family parties in Italy. An example of highly intimate social disclosure is shown in the following excerpt.

Intimate topics (e.g. disabilities, shame, failures): I open up myself quite a lot and speak about my mistakes and reveal my life experiences in that way. I reveal my human side. (Salesperson I)

During the renegotiation phase, some of the salespeople interviewed described how, having known each other for so long and collaborated on several projects that required spending a lot of time together, they felt that their customer from another culture had become something very close to a friend. The parties had discovered common interests and had become aware of similar personal characteristics. Therefore, in intercultural, interpersonal salesperson-customer relationships, the renegotiation phase can provide an environment suitable for a friendship to emerge (see also Grayson, 2007; Haytko, 2004).
Intercultural relationships development 
IMR

38,6

1204

Table 4.

Results of intercultural, interpersonal customer-salesperson relationships in the culturally diverse settings and salesperson's cultural intelligence level
Intercultural, interpersonal customer-salesperson relationships in culturally diverse settings

With regard to cultural diversity, the findings reveal that in those salesperson-customer relationships in which cultural diversity is low, the parties' similar cultural backgrounds foster an understanding between them. However, as Table 4 shows, these relationships did not develop greater depth, unlike relationships in which cultural diversity was high. In Table 4, it was found that the low cultural diversity relationships remained at either the trial or enmeshment phase; no relationships advanced to the renegotiation phase. The salespeople and customers appear to understand each other well, in line with the characterization of LC cultures as featuring explicit messages that contain most of the necessary information (Hall, 1977; Rosenbloom and Larsen, 2003). It appears then that low cultural diversity discourages the development of relationships so they enter the deepest phase because there is less need to renegotiate cultural identities.

In the trial phase, the parties noticed cultural differences, and neither the salespeople nor the customers had an interest in developing the relationships further:

I would not want to be too good friends with my customers ... the kind of very superficial friendship with the customer [is enough]. (Salesperson A)

But during the enmeshment phase, the partners started to recognise their similarities and deepened the relationship, reflecting common interests. Salesperson E, describing a relationship determined to be in the enmeshment phase, described being interested in the customer owing to shared hobbies but finding no reason to pursue the relationship further because their understanding seemed deep enough.

So, no it's not a friendship but it's not only a pure business relationship either. Somewhere in between ... if you say on a scale from one to 10 , where 10 is a friend and one is strictly a business partner, and that's it, I would probably [say], between five and six. But having said that we are both from Scandinavia. (Danish customer of Salesperson E.)

In contrast, most of the salesperson-customer relationships in which cultural diversity was high reached either the enmeshment or renegotiation phases (see Table 4). Whilst IMT predicts that it is harder to form "a mutually acceptable and convergent relational identity"

\begin{tabular}{|c|c|c|c|c|}
\hline $\begin{array}{l}\text { Low cultural diversity } \\
\text { between salesperson and } \\
\text { customer (low-low) }\end{array}$ & $\begin{array}{l}\text { Relationship } \\
\text { phase }\end{array}$ & $\begin{array}{l}\text { High cultural diversity between } \\
\text { salesperson and customer (low- } \\
\text { high) }\end{array}$ & $\begin{array}{l}\text { Relationship } \\
\text { phase }\end{array}$ & $\begin{array}{l}\text { Salesperson's } \\
\text { cultural } \\
\text { intelligence }\end{array}$ \\
\hline $\begin{array}{l}\text { Salesperson A - Swedish } \\
\text { customer }\end{array}$ & Trial & Salesperson A - Russian customer & Trial & Low \\
\hline $\begin{array}{l}\text { Salesperson B - Swedish } \\
\text { customer }\end{array}$ & Trial & Salesperson B - Russian customer & Trial & Low \\
\hline $\begin{array}{l}\text { Salesperson } \\
\text { C - Estonian customer }\end{array}$ & Enmeshment & Salesperson C - Russian customer & Trial & Low \\
\hline $\begin{array}{l}\text { Salesperson D - German } \\
\text { customer }\end{array}$ & Trial & Salesperson D - Korean customer & Trial & Low \\
\hline $\begin{array}{l}\text { Salesperson E - Danish } \\
\text { customer }\end{array}$ & Enmeshment & Salesperson E - Spanish customer & Enmeshment & Medium \\
\hline $\begin{array}{l}\text { Salesperson F - German } \\
\text { customer }\end{array}$ & Enmeshment & Salesperson F - Italian customer & Renegotiation & High \\
\hline $\begin{array}{l}\text { Salesperson G - Swedish } \\
\text { customer }\end{array}$ & Trial & Salesperson G - Chinese customer & Enmeshment & Medium \\
\hline $\begin{array}{l}\text { Salesperson H - Swedish } \\
\text { customer }\end{array}$ & Enmeshment & Salesperson H - Indian customer & Renegotiation & High \\
\hline $\begin{array}{l}\text { Salesperson I - Swedish } \\
\text { customer }\end{array}$ & Enmeshment & Salesperson I - Israeli customer & Renegotiation & High \\
\hline
\end{tabular}


(Cupach and Imahori, 1993, p. 125) with partners from different cultures, results show that both salespeople and customers were very interested in working with different cultures. They expressed a clear understanding of cultural diversity and sought to acquire cultural knowledge. The salespeople who had reached the renegotiation phase $(\mathrm{F}, \mathrm{H}$, and I) confirmed the IMT prediction that the relationship partners understand and accept their differences in the renegotiation phase and continue to be willing to develop and maintain the relationship. They also highlighted the importance of personal relationships, which helped them understand the more implicit messages in HC settings (Hall, 1977; Rosenbloom and Larsen, 2003). The partners noted strong levels of trust and commitment, and these deep relationships helped them arrive at complex solutions.

Some Italians have ... approvingly confirmed that the way I act when I am with them is like I am an Italian [friend]. (Salesperson F)

So, it is easy for me to become familiar with a person like this because we have some common interests. We love the seaside and also winter sports, so we discovered we have a lot of hobbies in common ... It was beautiful to have dinner together, to have a singing session, and so on. (Italian customer of Salesperson F)

\section{Salespersons' cultural intelligence}

The findings show how salespeople describe their cultural intelligence (CQ) as their intercultural, interpersonal salesperson-customer relationships evolve. Cultural intelligence (CQ) means a person's ability to adapt to new cultural settings and is a multidimensional construct with four dimensions (Earley and Ang, 2003). The findings are based on researchers' assessments of the salespeople's levels of CQ based on the qualitative interview data. The connection between CQ dimensions and the data as well as the assessment of CQ levels (as low, medium, or high) are explained in the appendix.

The summary of salespeople's CQ is shown in Table 4. The data indicate that the people interviewed had sufficient CQ to deal with less culturally diverse relationships. However, in high cultural diversity relationships, the need for heightened CQ requirements became evident.

Salespeople with low CQ (see Table 4, salespeople A-D) limited their relationships to the trial phase. Only Salesperson C had an enmeshment phase with an Estonian customer (low cultural diversity) because they had a mutual willingness to deepen their relationship. However, most of the salespeople with low CQ did not need to develop the relationship further, as the following quote reveals.

Business is business. I would not aim to develop a relationship [for business purposes]. (Salesperson D)

Salespeople with medium or high levels of CQ (Table 4, Salespeople E-I) were able to develop their relationships through to the enmeshment or renegotiation levels. Only Salesperson G, with medium CQ, reported being in a trial phase with a customer from a similar cultural background (low cultural diversity). That salesperson explained that there was no need to deepen the relationship with the Swedish customer. The deepest relationships were those built by the salespeople with the highest levels of CQ: F, H, and I. According to these salespeople, they share a mutual respect with their customers, and they also demonstrated their ability to perform facework:

Achieving personal trust is the starting point. And that can't be achieved in any other way than visiting the place often enough and being accepted as a person ... Well, it is about trust and keeping your promises, is not it? (Salesperson F)
Intercultural relationships development 
IMR

38,6

1206

I feel, I can trust [Salesperson F] because I think that he is an honest person . . . it is a really successful approach and, not only in terms of a personal relationship but also in term of the business. I think that both are benefiting about our relationship. (Italian customer of Salesperson F).

Finally, IMT (Imahori and Cupach, 2005) is leveraged to introduce a theoretical model to explicate the intercultural, interpersonal development of the relationship between salesperson and customer (see Figure 3). Intercultural, interpersonal salesperson-customer relationships can evolve from a trial phase toward enmeshment and renegotiation phases. Cultural diversity also plays a part in the relationship development process. Higher levels of cultural diversity seem to enhance relational identity formation between partners as well as more intimate social disclosure. A salesperson's CQ facilitates the relationship development process, as it was found that salespeople with higher levels of CQ were able to form the deepest relationships (and even move to the renegotiation phase).

\section{Discussion}

\section{Theoretical contributions}

Currently, we are living through the COVID-19 pandemic, and international marketing and sales have changed rapidly as travelling has become difficult and sales occur increasingly online (Bharadwaj and Shipley, 2020). Still, 86\% of sales representatives reported that the global crisis increased the importance of long-term customer relationships, and over $80 \%$ believe in the increased importance of building trust between partners both before and after a sale (Salesforce, 2020). This indicates that building and maintaining long-term customer relationships will be highly important in the anticipated future.

This study is the first to show how relational identity is formed between a salesperson from one culture, and a customer from another culture. The findings show that meanings are attached to each of the relationship stages, as the interpersonal, intercultural relationship deepens through trial, enmeshment, and renegotiation phases. In international sales,

Figure 3.

Theoretical model on intercultural, interpersonal salesperson-customer relationship development leveraging IMT in the context of international B2B solution selling

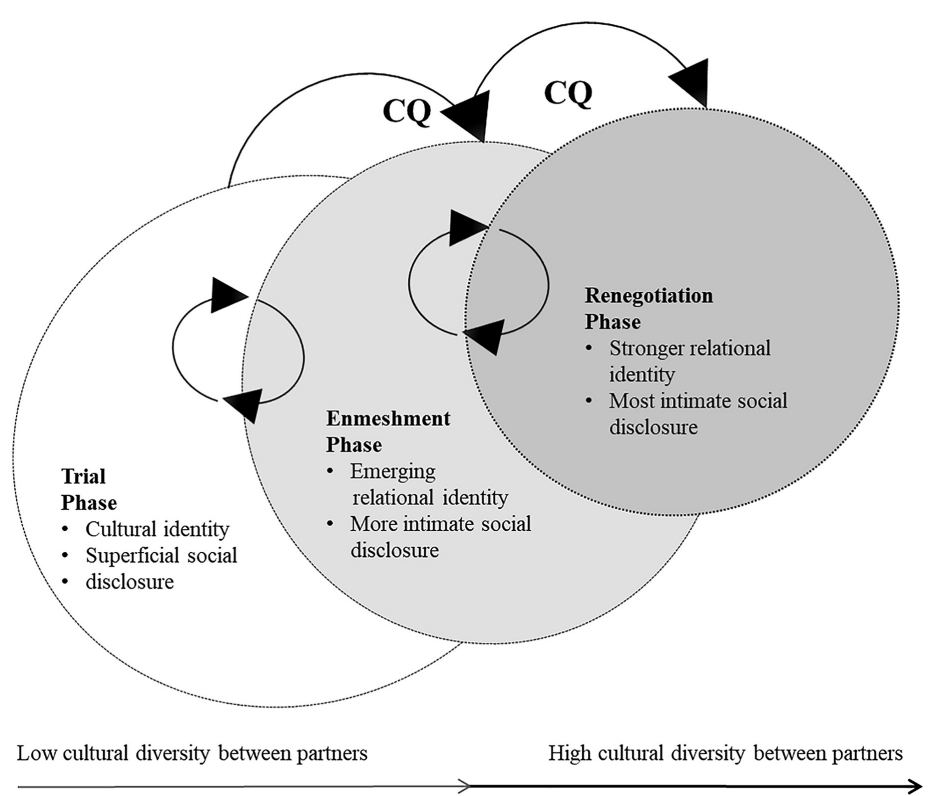


customer relationships may have many forms, however, marketing research has shown how customer-seller relationship depth is more critical to success when selling is more complex (e.g. Elo et al., 2015; Homburg et al., 2008; Palmatier, 2008). Therefore, it is important to understand how to develop the interpersonal, intercultural relationships towards deeper levels and how it brings value to the salesperson, their customer, and for their collaborative relationship (Terho et al., 2015).

This study contributes to the extant literature in the following ways: first, despite international marketing literature recognising the value of focusing on the interpersonal level (Esper et al., 2015; Fang et al., 2008; Ghauri et al., 2003; Kale et al., 2000; Miocevic, 2016), it lacks a theoretical perspective on $\mathrm{B} 2 \mathrm{~B}$ salesperson-customer relationships in the intercultural context. This study is the first research to bring IMT (Cupach and Imahori, 1993; Imahori and Cupach, 2005) to the field of international marketing, and to explore how intercultural, interpersonal salesperson-customer relationships evolve in culturally diverse settings. The findings indicate that among the respondents, the relationships investigated moved from trial toward enmeshment and even toward the renegotiation phase. Furthermore, this study shows how social disclosure between partners moved from a rather superficial level toward highly intimate sharing as the intercultural, interpersonal relationship evolved. It finds that low cultural diversity between salesperson and customer restrains interpersonal, intercultural relationship depth. However, where relationships are marked by high cultural diversity, those relationships develop toward deeper phases. This finding appears paradoxical compared with previous international marketing research that underlines how national cultural distance may adversely affect relationships through heightened communication barriers (Griffith, 2002), reduced trust, and constrained communication (Nes et al., 2007). Indeed, the findings of this study show that the strongest relational identity and most intimate social disclosure was found in customer relationships marked by high cultural distance, not in those featuring low cultural distance between partners.

Another contribution lies in identifying that a high level of CQ is an important requirement for international salespeople hoping to deepen their relationships, especially in contexts marked by high cultural diversity. Salesperson CQ can facilitate interpersonal relationship development in such a context. This constitutes a key contribution to previous international marketing research (Barnes et al., 2015). To the best of the authors' knowledge, no study has explored the role of $\mathrm{CQ}$ in facilitating intercultural relationships, particularly from the perspective of the development of a process-based, interpersonal relationship.

The findings of this study show that the salesperson's cultural intelligence (CQ) may be a facilitator of interpersonal relationship development in a context marked by high cultural diversity. Having a stronger relational identity may also positively strengthen interorganizational level collaboration. This finding on CQ addresses the question posed by Nes et al. (2007) on whether a high level of cultural sensitivity can compensate for eventual relationship problems grounded in the cultural distance between the parties. The indication is that salespeople may possess (or develop) a competency to deal with people from other cultures that helps to facilitate deeper relationship development in contexts where there is a cultural difference between B2B partners. Overall, these findings indicate that IMT is beneficial for understanding how intercultural, interpersonal salesperson-customer relationships evolve.

Prior research has established that not all customers want deep interpersonal relationships and that some customers view having such a relationship as a burden (Bettencourt et al., 2015). Salespeople need to be sensitive in this regard, as recent studies indicate that $\mathrm{B} 2 \mathrm{~B}$ buyers prefer searching information themselves and rely less on salespeople who they might consider to be biased related to the information they share (Rangajaran et al., 2019). Some B2B buyers prefer purchasing online once they have decided what to buy (Arli et al., 2018; Hoar, 2015). Furthermore, the findings of this study reveal
Intercultural relationships development 
IMR 38,6

equally that not all salespeople want - or see the need to develop - a deep interpersonal relationship with their customers. Some salespeople interviewed felt that having a deeper relationship with the customer could be a burden as well. Therefore, it is important to bear in mind that intercultural, interpersonal customer-salesperson relationships do not evolve toward deeper interpersonal levels without a reciprocal willingness and reciprocal needs influencing the partners.

Moreover, this study is unique in focusing on the development of interpersonal B2B customer-salesperson relationships in culturally diverse settings. Previous research tends to focus on firm-level relationships (Homburg and Stock, 2004; Morgan and Hunt, 1994; Wuyts and Geyskens, 2005). Considering the many relationship development studies available (e.g. Palmatier et al., 2013), little empirical research focuses on relationship development in crosscultural settings. Although prior research (e.g. Rodriquez, 2005; Chen et al., 1998) suggests that cultural diversity affects the nature of relationships, the research in this study is the first to explore how intercultural, interpersonal salesperson-customer relationships evolve in culturally diverse settings and solution-selling contexts.

Although applying IMT (Cupach and Imahori, 1993; Imahori and Cupach, 2005) would suggest that low cultural diversity should improve understanding in the interaction between salespeople and customers, and encourage deeper relationships between them because it is easier for partners to form deep relationships when both parties are from similar cultures, the findings of this study indicate the opposite. This study finds that low cultural diversity between salesperson and customer limits the depth achieved by the interpersonal, intercultural relationship. However, when relationships are marked by high cultural diversity, those relationships develop toward the enmeshment and renegotiation phases. The sellers featured in this study underlined that they were familiar with the customers when operating in a LC-LC context and therefore did not see the value in deepening these LC-LC relationships. Prior research shows the presumption of similarity in psychically close countries fosters complexity in management operations: complexity/situation constraints offer one explanation of why organizations' executives can struggle to address critical differences with partners from psychically close countries (Fenwick et al., 2003; O'Grady and Lane, 1996).

To conclude, the research of this study presents a theoretical model to aid understanding of intercultural, interpersonal salesperson-customer relationship development by leveraging IMT (Imahori and Cupach, 2005 (see Figure 3).

\section{Managerial implications}

International marketing ultimately entails some form of interaction and relationship-building between individuals, so international salespeople need to be able to form, maintain, and develop interpersonal customer relationships. Marketing researchers such as Rodriquez (2005) underscore that management practices should be congruent with a client's national culture. This study's findings also emphasise the importance of a seller's CQ in facilitating relationship development in $\mathrm{B} 2 \mathrm{~B}$ sales relationships across country borders.

The findings indicate that when cultural diversity is high, deep relationships become more important. It may be that the more diverse intercultural relationships add a degree of complexity and thus require deeper relationships (e.g. Elo et al., 2015; Homburg et al., 2008; Palmatier, 2008). Practically speaking then, sales managers should consider whether to hire salespeople who either are local and aware of the specific culture, who are experienced expatriates within that culture, or who have the passion and willingness to make personal contacts and allocate enough time and resources for salespeople to do so in a culturally intelligent way.

When cultural diversity is low, parties involved are familiar with each other's national cultures. In such situations, sales managers could coach their salespeople in how to allocate 
the appropriate, more limited, amount of time to deepen relationships at the interpersonal level as there is less need to spend time on exploring each other's national culture and the deepest relationships do not seem to be as important. Albeit, having a stronger relational identity may positively strengthen interorganizational level collaboration, so salespersons may do better in spending the time to deepen other relationships.

When faced with certain combinations in the B2B sales environment, the international salesperson must learn to assess the factors in play. Salespeople should then make appropriate, effective, and ethical decisions on the communication tactics and effort required to unleash their sales communication skills (Koponen et al., 2019) and deepen the salespersoncustomer relationship further. When deeper relationships are required, CQ should be utilised. Accordingly, this study suggests that managers should be aware of their salespeople's existing CQ level and incorporate training to enhance that CQ when preparing salespeople to operate in global business markets (Reichard et al., 2014).

\section{Limitations and further research}

One potential limitation is that existing relationships were studied at one point in time. Therefore, a longitudinal study would be beneficial in the future. In addition, interviewees' descriptions can never be complete; they rely on the informant's recall of the relationship, so an observational study could supplement the understanding of the topic. Finally, only HC-LC and LC-LC combinations were included to support the sample diversity aims of this study. While an LC-HC culturally diverse relationship should contain the same dynamics, the involvement of an $\mathrm{HC}$ salesperson could change the development of the relationship somewhat. Similarly, while this study anticipates how HC-HC low culturally diverse results would be similar to LC-LC, this assumption should be empirically tested. Furthermore, while it was anticipated that the findings would hold, there is a possibility that $\mathrm{HC}-\mathrm{HC}$ relationships might be deeper than the more straightforward communication required in an LC-LC relationship.

Further research should continue to explore this topic. Additional research is therefore suggested on other contextual factors/elements/environments that might exert an influence, because other settings may produce different insights (Haytko, 2004; Griffith and Hoppner, 2013). For example, future studies could test the model used in this study in countries in different states of economic development (e.g. industrial vs. industrialising economies or developing/developed country settings), and in different models of international business relationships (e.g. licensors and licensees (Leonidou et al., 2017)). In addition, even though the interviewees were asked to focus on long-term customer relationships that are on-going, still profitable over time, this could be measured in future studies. Researchers might examine other aspects of culture and the role of other organisational and strategic contingencies in the development and maintenance of high-quality intercultural, interpersonal relationships. Furthermore, future studies could advance our understanding on how and through which specific activities deeper customer relationships evolve. Researchers could also look at which activities capitalise on the salesperson's CQ in deepening relationships, and thus continued research incorporating friendship literature is encouraged as well. Moreover, it is also important to underline that future research should replicate this study by looking at relationship development and CQ from the customer perspective.

Since B2B sales increasingly occur online (Arli et al., 2018; Bharadwaj and Shipley, 2020), a more extensive understanding is required of how to manage $\mathrm{B} 2 \mathrm{~B}$ sales relationships in online and blended intercultural communication contexts. What are the roles of the customer and salesperson in digital B2B selling in the future? How are the parties able to form their relational identity when sales interaction is occurring mostly online? It might be that cultural differences are less obvious due to the fast-growing use of digital communication in sales and marketing globally (see also Jean et al., 2010), or that cultural differences might become more
Intercultural relationships development 
IMR

38,6

obvious as people have different tendencies in technology acceptance for example. To summarise, the current research helps to expose an important and potentially fruitful area of research that could contribute extensively to both the theory and managerial practice of international marketing.

\section{Notes}

1. In intercultural business settings, salespeople need cultural intelligence (CQ), defined as the ability to function, effectively manage, and behave appropriately in culturally diverse settings (Earley and Ang, 2003; Hansen et al., 2011). Hence, CQ is a communication competence and adaptability essential to IMT.

2. Our focus was on culturally diverse relationships. To explore this, we focused on LC salespeople with both LC and HC customers. Given power differentials between transacting parties, this work should not be generalised to relationships where the roles are reversed. This presents a limitation of the current work and a future research opportunity with two $\mathrm{HC}$ respondents or an $\mathrm{HC}$ salesperson with LC customers.

\section{References}

Alteren, G. and Tudoran, A.A. (2018), "Open-mindedness and adaptive business style: competences that contribute to building relationships in dissimilar export markets", International Marketing Review, Vol. 36, pp. 365-390.

Altman, I. and Taylor, D.A. (1973), Social Penetration: the Development of Interpersonal Relationships, Holt Rinehart and Winston, New York, NY.

Arli, D., Bauer, C. and Palmatier, R.W. (2018), "Relational selling: past, present and future", Industrial Marketing Management, Vol. 69, pp. 169-184.

Asseraf, Y., Lages, L.F. and Shoham, A. (2019), “Assessing the drivers and impact of international marketing agility", International Marketing Review, Vol. 36 No. 2, pp. 289-315.

Baack, D., Fogliasso, C. and Harris, J. (2000), "The personal impact of ethical decisions: a social penetration theory", Journal of Business Ethics, Vol. 24, pp. 39-49.

Bansal, H.S., Irving, P.G. and Taylor, S.F. (2004), "A three-component model of customer to service providers", Journal of the Academy of Marketing Science, Vol. 32 No. 3, pp. 234-250.

Barnes, B.R., Leonidou, L.C., Siu, N.Y.M. and Leonidou, C.N. (2015), "Interpersonal factors as drivers of quality and performance in Western-Hong Kong interorganizational business relationships", Journal of International Marketing, Vol. 23 No. 1, pp. 23-49.

Bettencourt, L.A., Blocker, C.P., Houston, M.B. and Flint, D.J. (2015), "Rethinking customer relationships", Business Horizons, Vol. 58 No. 1, pp. 99-108.

Bharadwaj, N. and Shipley, G.M. (2020), "Salesperson communication effectiveness in a digital sales interaction", Industrial Marketing Management, Vol. 90, pp. 106-112.

Bush, V.D., Rose, G.M., Gilbert, F. and Ingram, T.N. (2001), "Managing culturally diverse buyer-seller relationships: the role of intercultural disposition and adaptive selling in developing intercultural communication competence", Journal of the Academy of Marketing Science, Vol. 29, pp. 391-404.

Cannon, J.P., Doney, P.M., Mullen, M.R. and Petersen, K.J. (2010), "Building long-term orientation in buyer-supplier relationships: the moderating role of culture", Journal of Operations Management, Vol. 28 No. 6, pp. 506-521.

Chen, C.C., Chen, X. and Meindl, J.R. (1998), "How can cooperation be fostered? The cultural effects of individualism-collectivism”, Academy of Management Review, Vol. 23 No. 2, pp. 285-304.

Chen, X.P., Portnoy, R. and Liu, D. (2012), "A multilevel investigation of motivational cultural intelligence, organizational diversity climate, and cultural sales: evidence from US real estate firms", Journal of Applied Psychology, Vol. 97 No. 1, pp. 93-106. 
Chua, R.Y.J., Morris, M.W. and Mor, S. (2012), "Collaborating across cultures: cultural metacognition and affect-based trust in creative collaboration”, Organizational Behavior and Human Decision Processes, Vol. 118, pp. 116-131.

Cope, J. (2005), "Researching entrepreneurship through phenomenological inquiry. Philosophical and methodological issues”, International Small Business Journal, Vol. 23 No. 2, pp. 163-189.

Cupach, W.R. and Carson, C.L. (2002), "Characteristics and consequences of interpersonal complaints associated with perceived face threat", Journal of Social and Personal Relationships, Vol. 19 No. 4, pp. 443-462.

Cupach, W.R. and Imahori, T.T. (1993), "Identity management theory: communication competence in intercultural episodes and relationships", in Wiseman, R.L. and Koester, J. (Eds), Intercultural Communication Competence, Sage, Newbury Park, CA, pp. 112-131.

Dixon, A.L., Tanner, Jr and J.J.F. (2012), "Transforming selling: why it is time to think differently about sales research", Journal of Personal Selling and Sales Management, Vol. 32 No. 1, pp. 9-13.

Dwyer, F.R., Schurr, P.H. and Oh, S. (1987), "Developing buyer-seller relationships”, Journal of Marketing, Vol. 51 No. 2, pp. 11-27.

Earley, P.C. and Ang, S. (2003), Cultural Intelligence: Individual Interactions across Cultures, Stanford University Press, Palo Alto, CA.

Elo, M., Benjowsky, C. and Nummela, N. (2015), "Intercultural competences and interaction schemesfour forces regulating dyadic encounters in international business", Industrial Marketing Management, Vol. 48, pp. 38-49.

Esper, T.L., Bradley, R.V., Thomas, R. and Thornton, L.M. (2015), "Supply chain citizenship: investigating the antecedents of customer interorganizational citizenship behaviors", Journal of Business Logistics, Vol. 36 No. 4, pp. 306-320.

Evanschitzky, H., Wangenheim, F.V. and Woisetschläger, D.M. (2011), "Service and solution innovation: overview and research agenda", Industrial Marketing Management, Vol. 40 No. 5, pp. 657-660.

Fang, E., Palmatier, R.W., Scheer, L.K. and Li, N. (2008), "Trust at different organizational levels", Journal of Marketing, Vol. 72 No. 2, pp. 80-98.

Fenwick, M., Edwards, R. and Buckley, P.J. (2003), "Is cultural similarity misleading? The experience of Australian manufacturers in Britain”, International Business Review, Vol. 12 No. 3, pp. 297-309.

Fombelle, P.W., Bone, S.A. and Lemon, K.N. (2016), "Responding to the $98 \%$ : face-enhancing strategies for dealing with rejected customer ideas", Journal of the Academy of Marketing Science, Vol. 44 No. 6, pp. 1-22.

Ghauri, P., Lutz, C. and Tesfom, G. (2003), "Using networks to solve export-marketing problems of small-and medium-sized firms from developing countries", European Journal of Marketing, Vol. 37 Nos 5/6, pp. 728-752.

Goffman, E. (1967), Interaction Rituals, Anchor, Garden City, New York, NY.

Graebner, M.E. (2009), "Caveat venditor: trust asymmetries in acquisitions of entrepreneurial firms", Academy of Management Journal, Vol. 52 No. 3, pp. 435-472.

Grayson, K. (2007), "Friendship versus business in marketing relationships", Journal of Marketing, Vol. 71 No. 4, pp. 121-139.

Griffith, D.A. (2002), "The role of communication competencies in international business relationship development", Journal of World Business, Vol. 37 No. 4, pp. 256-265.

Griffith, D.A. and Hoppner, J.J. (2013), "Global marketing managers: improving global marketing strategy through soft skill development”, International Marketing Review, Vol. 30 No. 1, pp. 21-41.

Griffith, D.A., Myers, M.B. and Harvey, M.G. (2006), “An investigation of national culture's influence on relationship and knowledge resources in interorganizational relationships between Japan and the United States", Journal of International Marketing, Vol. 14 No. 3, pp. 1-32. 
IMR

38,6

Gummesson, E. (2008), Total Relationship Marketing, 3rd ed., Elsevier, Amsterdam.

Ha, J., Karande, K. and Singhapakdi, A. (2004), "Importers' relationships with exporters: does culture matter?", International Marketing Review, Vol. 21 Nos 4/5, pp. 447-461.

Halinen, A., Törnroos, J.Å. and Elo, M. (2013), "Network process analysis: an event-based approach to study business network dynamics", Industrial Marketing Management, Vol. 42 No. 8, pp. 1213-1222.

Hall, E.T. (1977), Beyond Culture, Anchor Press/Doubleday, Garden City, New York, NY.

Hall, E.T. and Hall, M.R. (1990), Understanding Cultural Differences, Intercultural Press, Yarmouth, ME.

Hansen, J.D., Singh, T., Weilbaker, D.C. and Guesalaga, R. (2011), "Cultural intelligence in crosscultural selling: propositions and directions for future research", Journal of Personal Selling and Sales Management, Vol. 31 No. 3, pp. 243-254.

Harima, A., Elo, M. and Freiling, J. (2016), "Rich-to-poor diaspora ventures: how do they survive", International Journal of Entrepreneurship and Small Business, Vol. 28 No. 4, pp. 391-413.

Haytko, D.L. (2004), "Firm-to-firm and interpersonal relationships: perspectives from advertising agency account managers", Journal of the Academy of Marketing Science, Vol. 32 No. 3, pp. 312-328.

Hewett, K. and Krasnikov, A.V. (2016), "Investing in buyer-seller relationships in transitional markets: a market-based assets perspective”, Journal of International Marketing, Vol. 24 No. 1, pp. 57-81.

Hewett, K., Money, R.B. and Sharma, S. (2006), "National culture and industrial buyer-seller relationships in the United States and Latin America", Journal of the Academy of Marketing Science, Vol. 34 No. 3, pp. 386-402.

Hoar, A. (2015), "Death of a (B2B) salesman”, available at: http://blogs.forrester.com/andy_hoar/15-0414-death_of_a_b2b_salesman (accessed 19 March 2021).

Homburg, C. and Stock, R.M. (2004), "The link between salespeople's job satisfaction and customer satisfaction in a business-to-business context: a dyadic analysis", Journal of the Academy of Marketing Science, Vol. 32 No. 2, pp. 144-158.

Homburg, C., Droll, M. and Totzek, D. (2008), "Customer prioritization: does it pay off, and how should it be implemented?", Journal of Marketing, Vol. 72 No. 5, pp. 110-130.

Homburg, C., Bornemann, T. and Kretzer, M. (2014), "Delusive perception-antecedents and consequences of salespeople's misperception of customer commitment", Journal of the Academy of Marketing Science, Vol. 42 No. 2, pp. 137-153.

Hoppner, J.J., Griffith, D.A. and White, R.C. (2015), "Reciprocity in relationship marketing: a cross-cultural examination of the effects of equivalence and immediacy on relationship quality and satisfaction with performance", Journal of International Marketing, Vol. 23 No. 4, pp. 64-83.

Hung, K.P. and Lin, C.K. (2013), "More communication is not always better? The interplay between effective communication and interpersonal conflict in influencing satisfaction", Industrial Marketing Management, Vol. 42 No. 8, pp. 1223-1232.

Imahori, T.T. and Cupach, W.R. (2005), "Identity management theory. Facework in intercultural relationships", in Gudykunst, W.B. (Ed.), Theories about Intercultural Communication, Sage Publications, Thousand Oaks, CA, pp. 195-210.

Imai, L. and Gelfand, M.J. (2010), "The culturally intelligent negotiator: the impact of cultural intelligence (CQ) on negotiation sequences and outcomes", Organizational Behavior and Human Decision Processes, Vol. 112, pp. 83-98.

Jacobs, R.S., Evans, K.R., Kleine, R.E. III and Landry, T.D. (2001a), "Disclosure and its reciprocity as predictors of key outcomes of an initial sales encounter", Journal of Personal Selling and Sales Management, Vol. 21 No. 1, pp. 51-61. 
Jacobs, R.S., Hyman, M.R. and McQuitty, S. (2001b), "Exchange-specific self-disclosure, social selfdisclosure, and personal selling", Journal of Marketing Theory and Practice, Vol. 9 No. 1, pp. $48-62$.

Jean, R.J.B., Sinkovics, R.R. and Kim, D. (2010), "Drivers and performance outcomes of relationship learning for suppliers in cross-border customer-supplier relationships: the role of communication culture", Journal of International Marketing, Vol. 18 No. 1, pp. 63-85.

Kale, P., Singh, H. and Perlmutter, H. (2000), "Learning and protection of proprietary assets in strategic alliances: building relational capital”, Strategic Management Journal, Vol. 21 No. 3, pp. 217-237.

Katsikeas, C.S., Skarmeas, D.A. and Bello, D.C. (2009), "Developing successful trust-based international exchange relationships", Journal of International Business Studies, Vol. 40 No. 1, pp. 132-155.

Kauser, S. and Shaw, V. (2004), "The influence of behavioural and organizational characteristics on the success of international strategic alliances”, International Marketing Review, Vol. 21 No. 1, pp. 17-52.

Khakhar, P. and Rammal, H.G. (2013), "Culture and business networks: international business negotiations with Arab managers", International Business Review, Vol. 22 No. 3, pp. 578-590.

Koponen, J., Julkunen, S. and Asai, A. (2019), "Sales communication competence in B2B solution selling”, Industrial Marketing Management, Vol. 82, pp. 238-252.

Kudo, K. and Simkin, K.A. (2003), "Intercultural Friendship Formation: the case of Japanese students at an Australian university", Journal of Intercultural Studies, Vol. 24 No. 2, pp. 91-114.

Lee, P.W. (2008), "Stages and transitions of relational identity formation in intercultural friendship: implications for identity management theory", Journal of International and Intercultural Communication, Vol. 1 No. 1, pp. 51-69.

Leonidou, L.C., Aykol, B., Fotiadis, T.A. and Christodoulides, P. (2017), "Antecedents and consequences of infidelity in cross-border business relationships", Journal of International Marketing, Vol. 25 No. 1, pp. 46-71.

Littlejohn, S.W. and Foss, K.A. (2010), Theories of Human Communication, Waveland Press, Longrove, IL.

Liu, A.H. and Leach, M.P. (2001), "Developing loyal customers with a value-adding sales force: examining customer satisfaction and the perceived credibility of consultative salespeople", Journal of Personal Selling and Sales Management, Vol. 11 No. 2, pp. 147-156.

Makkonen, H., Aarikka-Stenroos, L. and Olkkonen, R. (2012), "Narrative approach in business network process research-implications for theory and methodology", Industrial Marketing Management, Vol. 41 No. 2, pp. 287-299.

Miles, M.B. and Huberman, A.M. (1994), Qualitative Data Analysis: an Expanded Sourcebook, Sage Publications, Thousand Oaks, CA.

Miocevic, D. (2016), “The antecedents of relational capital in key exporter-importer relationships", International Marketing Review, Vol. 33 No. 2, pp. 196-218.

Möller, K. (2011), "A solution business model: capabilities and management practices for integrated solutions", Industrial Marketing Management, Vol. 40, pp. 699-711.

Moon, T. (2013), "The effects of cultural intelligence on performance in multicultural teams", Journal of Applied Social Psychology, Vol. 43, pp. 2414-2425.

Morgan, R.M. and Hunt, S.D. (1994), “The commitment-trust theory of relationship marketing”, Journal of Marketing, Vol. 58, pp. 20-38.

Nes, E.B., Solberg, C.A. and Silkoset, R. (2007), "The impact of national culture and communication on exporter-distributor relations and on export performance", International Business Review, Vol. 16 No. 4, pp. 405-424. 
IMR

38,6

1214

O'Grady, S. and Lane, H.W. (1996), "The psychic distance paradox", Journal of International Business Studies”, Vol. 27 No. 2, pp. 309-333.

Palmatier, R.W. (2008), "Interfirm relational drivers of customer value", Journal of Marketing, Vol. 72 No. 4, pp. 76-89.

Palmatier, R.W., Houston, M.B., Dant, R.P. and Grewal, D. (2013), "Relationship velocity: toward a theory of relationship dynamics", Journal of Marketing, Vol. 77 No. 1, pp. 13-30.

Paparoidamis, N.G., Tran, H.T.T. and Leonidou, C.N. (2019), "Building customer loyalty in intercultural service encounters: the role of service employees' cultural intelligence", Journal of International Marketing, Vol. 27 No. 2, pp. 56-75.

Pothukuchi, V., Damanpour, F., Choi, J., Chen, C.C. and Park, S.H. (2002), "National and organizational culture differences and international joint venture performance", Journal of International Business Studies, Vol. 33 No. 2, pp. 243-265.

Rammal, H.G. (2005), "International business negotiations: the case of Pakistan”, International Journal of Commerce and Management, Vol. 15 No. 2, pp. 129-140.

Rangajaran, D., Guenzi, P. and Kaski, T. (2019), "Mastering digital transformation in sales: a research agenda going forward", Proceedings of the Annual Global Sales Science Institute Conference 2019 Panama, Global Sales Science Institute, Aalen, pp. 44-55.

Reichard, R.J., Dollwet, M. and Louw-Potgieter, J. (2014), "Development of cross-cultural psychological capital and its relationship with cultural intelligence and ethnocentrism", Journal of Leadership and Organizational Studies, Vol. 21 No. 2, pp. 150-164.

Riessman, C.K. (2004), "Narrative analysis”, in Lewis-Beck, M.S., Bryman, A. and Futing Liao, T. (Eds), Encyclopedia of Social Science Research Methods, Sage Publications, London and Newbury Park CA, pp. 705-709.

Rodríguez, C.M. (2005), "Emergence of a third culture: shared leadership in international strategic alliance”, International Marketing Review, Vol. 22 No. 1, pp. 67-95.

Rosenbloom, B. and Larsen, T. (2003), "Communication in international business-to-business marketing channels. Does culture matter?”, Industrial Marketing Management, Vol. 32, pp. 309-315.

Salesforce (2020), “The internet 19.03.2021", available at: https://c1.sfdcstatic.com/content/dam/web/ en_us/www/documents/research/Salesforce-State-of-Sales-4th-Ed.pdf (accessed 19 March 2021).

Sharma, A., Iyer, G.R. and Evanschitzky, H. (2008), "Personal selling of high-technology products: the solution-selling imperative”, Journal of Relationship Marketing, Vol. 7 No. 3, pp. 287-308.

Spekman, R.E. and Carraway, R. (2006), "Making the transition to collaborative buyer-seller relationships: an emerging framework", Industrial Marketing Management, Vol. 35, pp. 10-19.

Spiro, R.L. and Weitz, B.A. (1990), "Adaptive selling: conceptualization, measurement, and nomological validity", Journal of Marketing Research, Vol. 27 No. 1, pp. 61-69.

Stanko, M.A., Bonner, J.M. and Calantone, R.J. (2007), "Building commitment in buyer-seller relationships: a tie strength perspective", Industrial Marketing Management, Vol. 36 No. 8, pp. 1094-1103.

Stock, C. (2012), "Adaptation and empathy: intercultural communication in a choreographic project", Journal of Intercultural Studies, Vol. 33 No. 4, pp. 445-462.

Terho, H. and Halinen, A. (2012), "The nature of customer portfolios: towards new understanding of firms' exchange contexts", Journal of Business-To-Business Marketing, Vol. 19 No. 4, pp. 335-366.

Terho, H., Eggert, A., Haas, A. and Ulaga, W. (2015), "How sales strategy translates into performance: the role of salesperson customer orientation and value-based selling", Industrial Marketing Management, Vol. 45, pp. 12-21.

Thompson, C.J., Locander, W.B. and Pollio, H.R. (1989), "Putting consumer experience back into consumer research: the philosophy and method of existential phenomenology", Journal of Consumer Research, Vol. 16, pp. 133-147. 
Tuli, K.R., Kohli, A.K. and Bharadwaj, S.G. (2007), "Rethinking customer solutions: from product bundles to relational processes", Journal of Marketing, Vol. 71 No. 3, pp. 1-17.

Viio, P. and Grönroos, C. (2016), "How buyer-seller relationship orientation affects adaptation of sales processes to the buying process", Industrial Marketing Management, Vol. 52, pp. 37-46.

Voldnes, G., Grønhaug, K. and Nilssen, F. (2012), "Satisfaction in buyer-seller relationships-influence of cultural differences", Industrial Marketing Management, Vol. 41 No. 7, pp. 1081-1093.

Weitz, B.A. and Bradford, K.D. (1999), "Personal selling and sales management: a relationship marketing perspective", Journal of the Academy of Marketing Science, Vol. 27 No. 2, pp. 241-254.

Wu, P.C. and Ang, S.H. (2011), "The impact of expatriate supporting practices and cultural intelligence on cross-cultural adjustment and performance of expatriates in Singapore", The International Journal of Human Resource Management, Vol. 22 No. 13, pp. 2683-2702.

Wuyts, S. (2007), "Extra-role behaviour in buyer-supplier relationships", International Journal of Research in Marketing, Vol. 24 No. 4, pp. 301-311.

Wuyts, S. and Geyskens, I. (2005), "The formation of buyer-supplier relationships: detailed contract drafting and close partner selection”, Journal of Marketing, Vol. 69 No. 4, pp. 103-117.

Zhang, C., Cavusgil, S.T. and Roath, A.S. (2003), "Manufacturer governance of foreign distributor relationships: do relational norms enhance competitiveness in the export market?", Journal of International Business Studies, Vol. 334 No. 6, pp. 550-556.

Zhou, J., Zhang, C., Shen, L. and Zhou, K.Z. (2020), "Interpersonal Guanxi and partner extra-role behaviour: mediating role of relational and transactional governance strategy", Industrial Marketing Management, Vol. 91, pp. 551-562, doi: 10.1016/j.indmarman.2020.03.022.

\section{Further reading}

Panagopoulos, N.G. and Avlonitis, G.J. (2010), "Performance implications of sales strategy: the moderating effects of leadership and environment", International Journal of Research in Marketing, Vol. 27 No. 1, pp. 46-57.

\section{Corresponding author}

Mika Gabrielsson can be contacted at: mika.gabrielsson@uef.fi
Intercultural relationships development 


\section{Appendix}

38,6

Dimension of $\mathrm{CQ}$

(1) Cognitive CQ involves knowledge of cultures

1216
(2) Metacognitive CQ reflects the person's cultural awareness during intercultural communication

(3) Motivational CQ involves emotional aspects, such as a willingness to adapt to a new culture, enjoyment interacting with that new culture, and feeling confident about doing so

(4) Behavioural CQ deals with interactions, including verbal and nonverbal skills and the ability to perform facework

Level of salesperson's

CQ

Low level of $\mathrm{CQ}$

Medium level of CQ

Table A1.

Cultural intelligence

(CQ) dimensions and quotes from the data, as well as CQ levels and explanations
Quotation from the data

(1) "In the end, Sweden is quite similar to Finland [re. Norms, practices, conventions] ... In Western countries you pretty much have the same rules" (Salesperson B)

(2) "In Asia, the most important thing is to be aware of the environment and the hierarchical relationships [cultural bound thinking processes], because there it is very easy to unintentionally embarrass someone or make some stupid mistake that nobody even knew about" (Salesperson I)

(3) "I have been told I am just like an Italian. In Italy you have to be flexible and if you want something, you may have to give ground in something else. It is not like it is with the Germans" (Salesperson F)

(4) "I am trying to learn the language even just a little. It shows that you are making an effort and that shows respect." Facework: "As a woman in a culture such as Turkey, I had to make some concessions so that the CEO would not lose face" (Salesperson D)

Explanation

Salespeople described mostly motivational CQ and metacognitive CQ. They were conscious of the cultural knowledge required when interacting with customers with different cultural backgrounds

Salespeople described motivational CQ, metacognitive CQ, and behavioural CQ. They were conscious of the cultural knowledge required in cross-cultural environments. They were also willing to communicate with customers from different cultures and learn about cultural diversity. Furthermore, they often paid attention to their communication behaviour when interacting with customers with different cultural backgrounds

Salespeople described motivational CQ, cognitive CQ, metacognitive CQ, and behavioural CQ. The salespeople had a strong awareness of cultural diversity in their customer relationships. They were interested in understanding their customers' values, rules, and the economic systems of different cultures 